\title{
Comparison of Destructive and Non-Destructive Method in Maturity Index of Garcinia mangostana
}

\author{
DOI: $10.18196 /$ pt.2018.086.100-105
}

\section{Indira Prabasari}

Department of Agrotechnology, Faculty of Agriculture, Universitas Muhammadiyah Yogyakarta, Jl. Brawijaya, Kasihan, Bantul Yogyakarta 55183, Indonesia, Telp: +62 274 387656, Faks: +62 274387646 email: sariindira@umy.ac.id

\begin{abstract}
Postharvest maturity index for mangosteen (Garcinia mangostana L) is very important for picking and grading during postharvest processing. Skin color change is the primary maturity index for mangosteen. However, determination using human eyes needs many skilled labours and is inconsistent. Therefore, new method in image processing technology using SVM (Support Vector Machine) was employed in this study. Chemical analysis of mangosteen was performed and used as a reference of SVM method. The chemical analysis of mangosteen showed that anthocyanin content increased from 126.20 ppm at stage 1 to 213.98 ppm at stage 6. Reducing sugar content increased from 3.17\% at stage 1 to $7.92 \%$ at stage 6. The same pattern was found for total soluble solid, an increase from 3.86\% at stage 1 to $7.81 \%$ at stage 6 . Whereas for total acid content and hardness the pattern was the opposite. Total acid content was decreased from $1.78 \%$ at stage 1 to $1.06 \%$ at stage 6 and the fruit hardness of mangosteen was also declined, showing the number from 4.30 N at stage 1 to $0.69 \mathrm{~N}$ at stage 6. For SVM method, image aquisition was conducted for mangosteen images from stage 1 to stage 6, followed by color feature extraction for each stages. The result was trained and tested using SVM and resulted accuracy level of 83.3\%.

Keywords: Mangosteen, Support vector machine, Maturity index, Non-destructive method
\end{abstract}

\section{ABSTRAK}

Indeks kematangan pascapanen untuk manggis (Garcinia mangostana L.) sangat penting pada pemetikan dan grading selama pemrosesan pascapanen. Perubahan warna kulit adalah indeks kematangan utama untuk manggis. Namun, penentuan tingkat kematangan dengan mata manusia membutuhkan banyak tenaga terampil dan tidak konsisten. Oleh karena itu, metode baru dalam teknologi pemrosesan gambar menggunakan SVM (Support Vector Machine) digunakan dalam penelitian ini. Analisis kimia manggis dilakukan dan digunakan sebagai referensi metode SVM. Analisis kimia manggis menunjukkan bahwa kandungan antosianin meningkat dari 126,20 ppm pada tahap 1 menjadi 213,98 ppm pada tahap 6. Penurunan kadar gula meningkat dari 3,17\% pada tahap 1 menjadi 7,92\% pada tahap 6. Pola yang sama ditemukan untuk total padatan terlarut, peningkatan dari 3,86\% pada tahap 1 menjadi 7,81\% pada tahap 6. Sedangkan untuk kadar asam total dan kekerasan pola sebaliknya. Total kandungan asam menurun dari 1,78\% pada tahap 1 menjadi 1,06\% pada tahap 6 dan kekerasan buah manggis juga menurun, menunjukkan jumlah dari 4,30 N pada tahap 1 menjadi 0,69 N pada tahap 6. Untuk metode SVM, image aquisition dilakukan untuk gambar manggis dari tahap 1 ke tahap 6, diikuti oleh ekstraksi fitur warna untuk setiap tahap. Hasilnya diuji menggunakan SVM dan menghasilkan tingkat akurasi 83,3\%.

Kata Kunci: Manggis, Support Vector Machine, Indeks kematangan, Metode non-destruktif

\section{INTRODUCTION}

Mangosteen (Garcinia mangostana L.) is a climacteric fruit with white flesh, juicy and sweet taste. The peel of mangosteen fruit (pericarp) is dark purple and rich with secondary metabolites of active compounds including anthocyanins, oligomers proanthocyanins and xantone (Fu et al., 2007; Jie, et al., 2007). Mangosteen is very popular in Indonesia and it is one of major horticultural export products. The export of mangosteen significantly increased. However, there is only approx. $11.79 \%$ which is eligible to be exported due to the low quality of the fruit. The high post-harvest loss is caused by the difficulty of mangosteen maturity detection that results in declining quality of fruit (Palapol, et al., 2009).

Mangosteen is usually picked when the color is pink to red across the peel. If it is picked too early, the fruit will not be ripe perfectly and it degrades the quality (Tongdee and Suwanagul, 1989; Paull and Ketsa, 2004; Palapol, et al., 2009). The low quality of mangosteen makes the fruit declined for export purposes and that is a loss for the farmer since the price of mangosteen overseas is about 5-8 higher than the local marketplace (Suyanti and Setyadjit, 2007).

The purplish red color skin in mangosteen is 


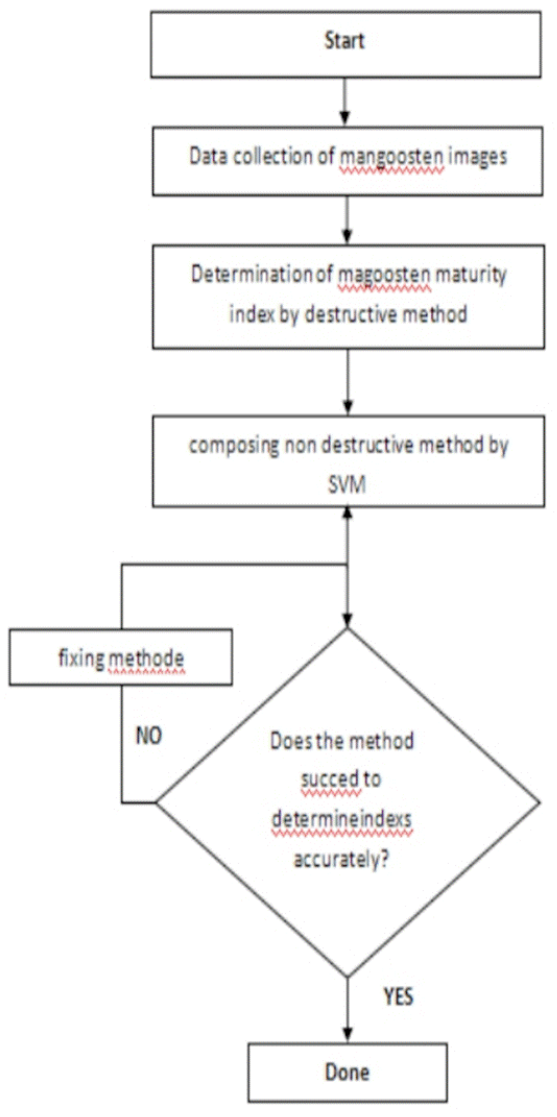

Figure 1. Development of Non-Destructive Method for Mangosteen Maturity Index

caused by the anthocyanin pigments. Anthocyanin is a pigment found in mangosteen when the fruit is ripe. The identification of mangosteen color can be measured visually or with destructive analysis using HPLC, Spectrophotometer, GC/MS and other chemical analysis. Measurement done by human eyes is usually subjective and inconsistent and the measurement can differ from one person to another. Meanwhile destructive method requires the fruit to be destroyed through stages of complex analysis that take a long time to finish. Therefore, it is important to develop a nondestructive method in determining the ripeness of the fruit. Mechanical analysis of non-destructive ends for ripeness by color using a "neural network" (NN) and fuzzy already widely tested (Riyadi, et.al., 2007a; Riyadi, et.al., 2007b). Recently a new technique has been developed that is "support vector machine" (SVM) which has a higher degree of accuracy. Testing SVM on mangoes showed very good results with a 95\% accuracy rate (Nandi et al., 2014).

\section{MATERIAL AND METHODS}

Mangosteen

Mangosteen was obtained from a fruit plantation in Purworejo, Central Java, Indonesia. The fruit was immediately brought to the Post Harvest Laboratory, Faculty of Agriculture Universitas Muhammadiyah Yogyakarta, Indonesia (UMY) and stored at room temperature. Mangosteen was classified based on the maturity level visually and divided into six criteria of maturity (Standard ASEAN STAN 10; 2008):

Stage 0: yellowish white or yellowish white with $5-50 \%$ scattered pink spots

Stage 1: light greenish yellow with 5-50\% scattered pink spots

Stage 2: light greenish yellow with $51-100 \%$ scat tered pink spots

Stage 3: spots not as distinct as in stage 2

Stage 4: red to reddish purple

Stage 5: dark purple

Stage 6: purple black

\section{Method of Destructive Fruit Maturity}

Detection of maturity with destructive methods was performed to obtain the reference data of mangosteen maturity.

\section{Extraction of anthocyanin}

Methods of extraction and isolation of anthocyanins were modified from Lestario et al. (2011). Mangosteen peel was cut into small pieces then macerated with methanol containing $1 \% \mathrm{HCl}$ in 1: $4(\mathrm{w} / \mathrm{v})$ overnight at $5^{\circ} \mathrm{C}$. The filtrate was filtered with Whatman no. 1 and partitioned with a separating funnel with the addition of diethyl ether to separate the components of non-anthocyanin (Ozela, et al., 2007). To add polarity in order to 


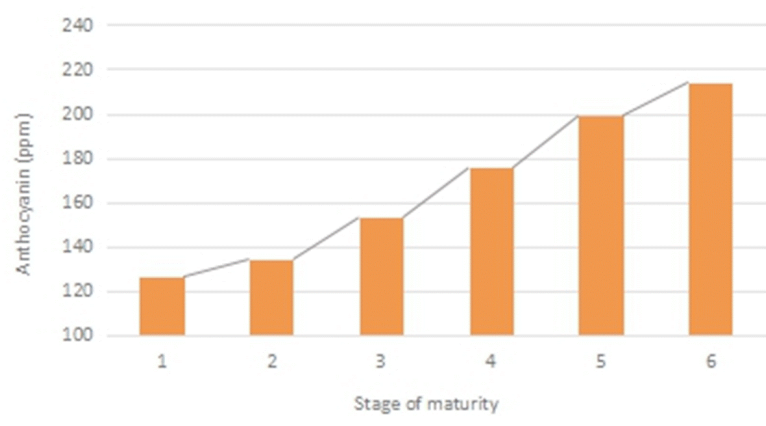

Figure 2. The Increase of Anthocyanin Content During Ripening of Mangosteen

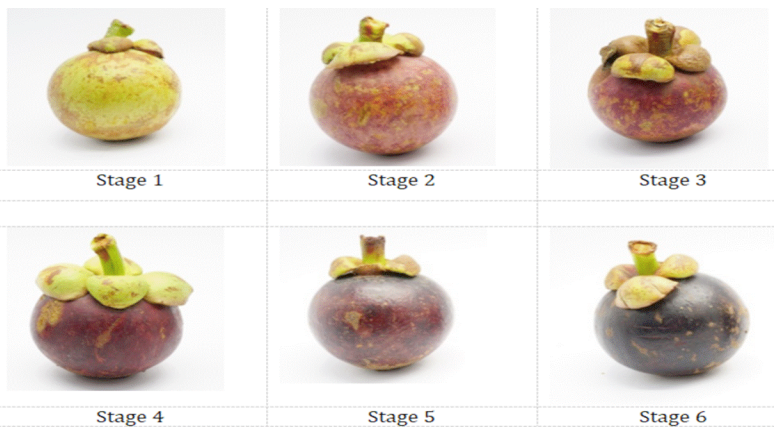

Figure 3. Maturity stages of mangosteen during ripening. The skin color changed from yellow green in stage 1 to deep purple in stage 6

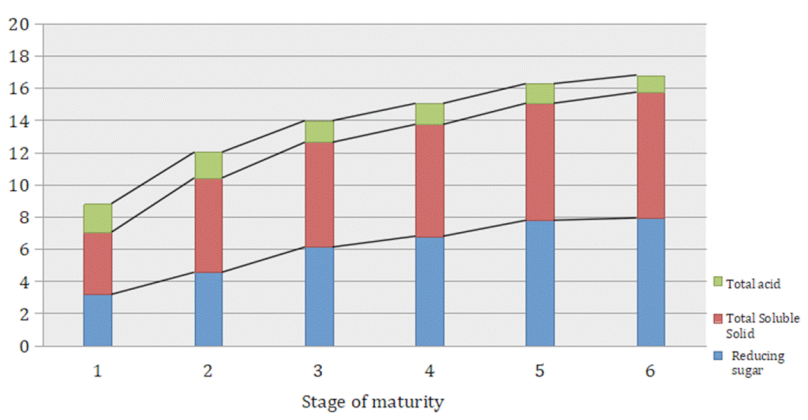

Figure 4. The increase of reducing sugar, total soluble solid and total acid during ripening of mangosteen

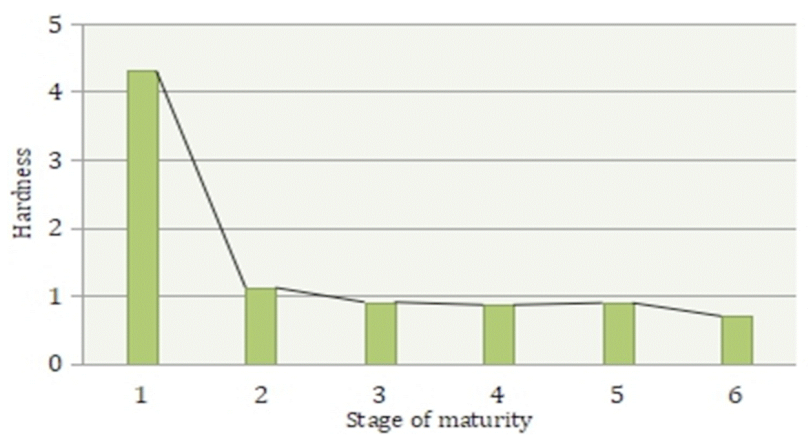

Figure 5. The Decrease of Hardness During Ripening of Mangosteen separate solvent well, it was added distilled water (filtrate volume ratio: diethyl ether: distilled water $=1: 2: 1)$.

\section{Total Content of Anthocyanin}

Method from Giusti and Wrolstad (1996) was used to determine the total anthocyanin content in the skin of mangosteen. Anthocyanin extract was dissolved in $\mathrm{KCl}-\mathrm{HCl}$ buffer (1M, pH 1) and $\mathrm{NaOAc}$ buffer (1M, pH 4.5) with a ratio of extract against buffer was 1: $5(\mathrm{v} / \mathrm{v})$. Each solution was measured its absorbance at $520 \mathrm{~nm}$ and $700 \mathrm{~nm}$ after incubation for $15 \mathrm{~min}$ at $\mathrm{RT}$ and the results was incorporated into the formula $A=\left[\left(A_{510}-A_{700}\right)\right.$ $\left.{ }_{\mathrm{pH} 1}-\left(\mathrm{A}_{510}-\mathrm{A}_{700}\right)_{\mathrm{pH} 4,5}\right]$ and calculation was incorporated into the law of Lambert-Beer that $A=\varepsilon$.L.C.

\section{Analysis of Reducing Sugar}

Reducing sugar analysis was done using Nelson-Somogyi method. Mangosteen flesh was destroyed and filtered. Sample of $1 \mathrm{~mL}$ was added with distilled water up to $10 \mathrm{~mL}$ and taken $1 \mathrm{~mL}$ to be added with $9 \mathrm{~mL}$ of distilled water. Diluted samples were taken $1 \mathrm{~mL}$ and mixed with Nelson mixture (Nelson mixture of A and B 25: $1(\mathrm{v} / \mathrm{v})$ ) then heated at $100^{\circ} \mathrm{C}$ for $20 \mathrm{~min}$. The sample was cooled at RT. Sample was added with $1 \mathrm{~mL}$ of arsenomolybdat and $7 \mathrm{~mL}$ of distilled water and then shaken. The absorption of the sample was measured at $510 \mathrm{~nm}$.

\section{Analysis of Total Soluble Solid (TSS)}

TSS analysis was done by destroying the flesh of mangosteen then it was sealed with a refractometer (Atago, Tokyo, Japan) and calibrated with distilled water.

\section{Analysis of Titratable Acid (TA)}

It was conducted by making a filtrate flesh of mangosteen $(5 \mathrm{~mL})$ and then titrated with $0.1 \mathrm{M}$ $\mathrm{NaOH}$. 
Fruit Hardness Test

Fruit hardness test was done with a hand-held penetrometer.

Non-destructive methods in detection of fruit maturity by image processing technology

The application of non-destructive methods on mangosteen in this study was conducted in three main phases: 1) data collection, 2) determining the maturity index of the mangosteen with a destructive method, 3) the manufacturing method of non-destructive method SVM and 4) validation of the results, such as shown in Figure 1.

The description of each phases of the development of non-destructive methods for mangosteen maturity as follows:

\section{Data collection of Mangosteen}

At this stage, mangosteen was photographed to obtain image data of mangosteen maturity from stage 1 to stage 6 . The fruit was photographed using digital camera with $24 \mathrm{mp}$ CMOS sensor in a light box of $60 \times 40 \times 50 \mathrm{~cm}$ to create even lighting.

\section{Establishing image processing technology method}

The process of SVM method began with the extraction of RGB (red, green blue) color features of mangosteen image. RGB features were summed and averaged for each color and 6 values were processed in the SVM method.

\section{Results validation}

Validation of the results was done to determine whether the determination of maturity index with SVM method gave accurate results as the destructive method. The data reference was the concentration of anthocyanin content and supporting data including sugar, TSS, TA and fruit hardness test.

\section{RESULTS AND DISCUSSION}

Destructive method in fruit maturity detection
Ripening process of mangosteen from stage 1 to 6 showed an increase in anthocyanin content from $126.20 \mathrm{ppm}$ at stage 1 to $213.98 \mathrm{ppm}$ at

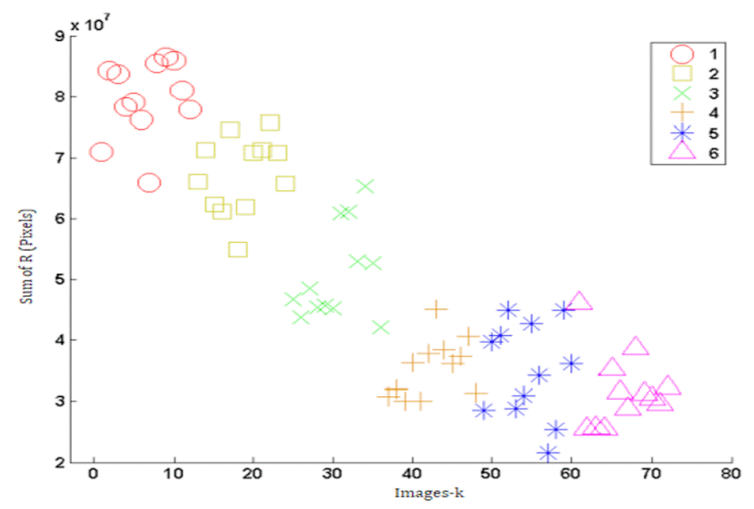

Figure 6. Scatter Plot From Sum of R (red)

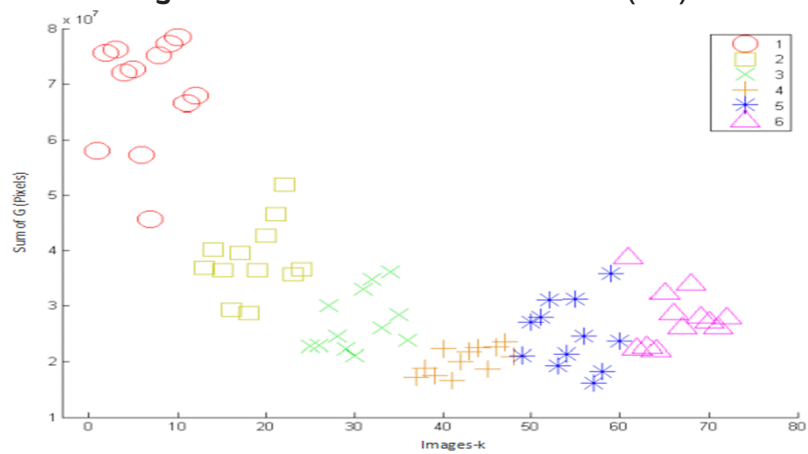

Figure 7. Scatter Plot From Sum of G (green)

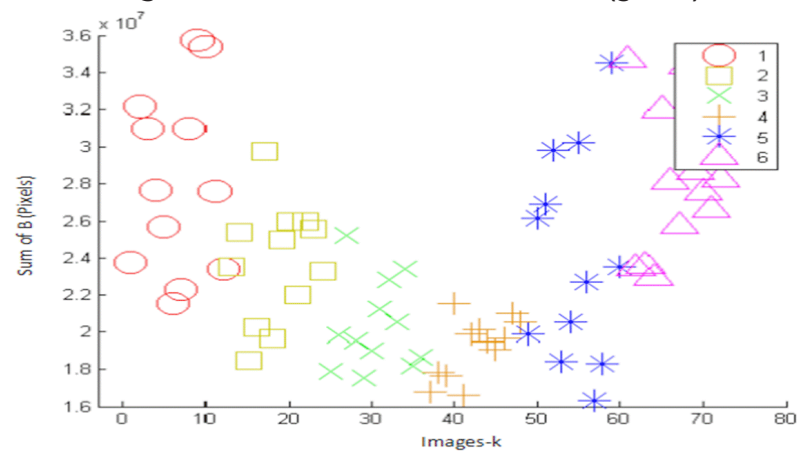

Figure 8. Scatter Plot from Sum of B (blue)

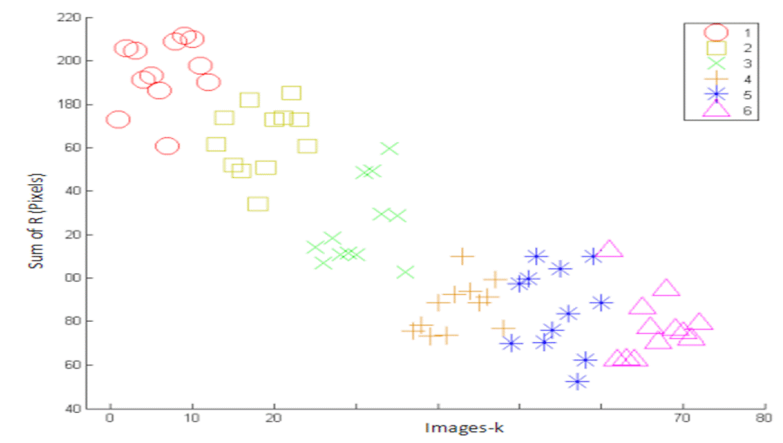

Figure 9. Scatter Plot from Mean of R (red) 


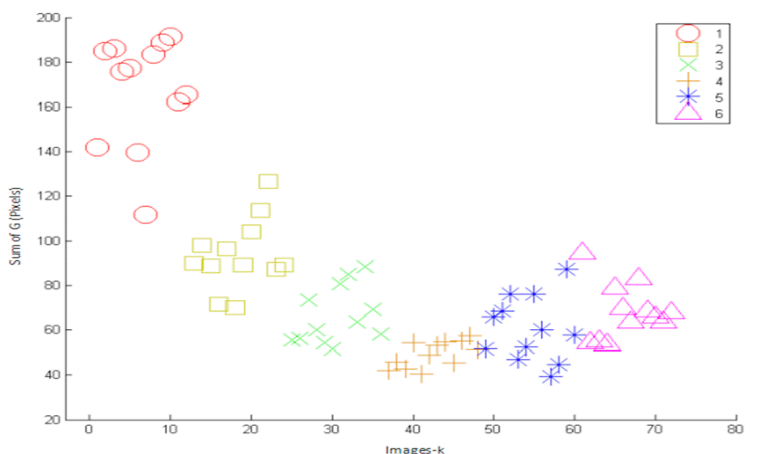

Figure 10. Scatter Plot from Mean of G (green)

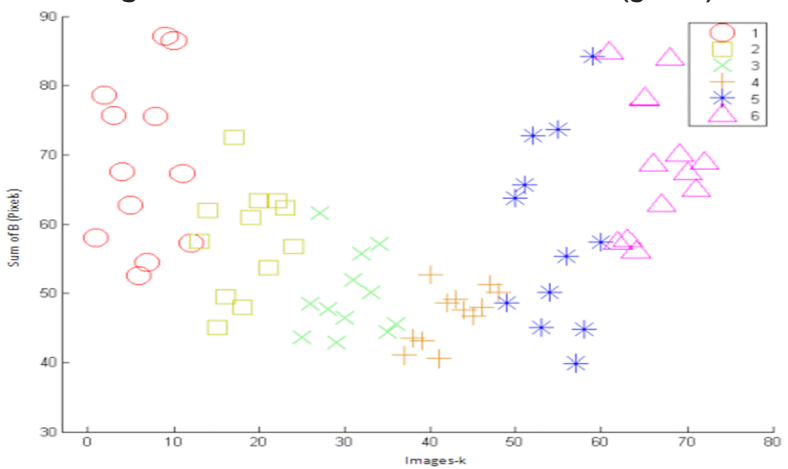

Figure 11. Scatter plot from mean of B (blue)

stage 6 (Figure 2). The increase of anthocyanin was reflected in the change of its skin color from stage 1 to stage 6 as shown in Figure 3. The skin color changes correlated with ethylene production and it was shown by our data on other chemical compound changes that will be discussed later. Studies showed that the development of peel color in outer pericarp of mangosteen was correlated with the increase of cyanidin-3-sophoroside and the cyanidin-3-glucosides during ripening process (Palopol et al., 2009). Reducing sugar increased from $3.17 \%$ at stage 1 to $7.92 \%$ at stage 6 during ripening process as shown in Figure 4, and this indicated glycolysis process where polysaccharides converted into glucose. This finding was supported by the increase of total soluble solids from $3.86 \%$ at stage 1 to $7.81 \%$ at stage 6 and the decrease of total acid content from $1.78 \%$ at stage 1 to $1.06 \%$ at stage 6 as shown in Figure 4. This phenomenon was affected by the increase in ethylene production during ripening process of mangosteen as suggested by Palopol et.al. (2009). Figure 5 showed the decrease of hardness from $4.30 \mathrm{~N}$ at stage 1 to $0.69 \mathrm{~N}$ at stage 6 indicated degradation of pectin in the cell wall, and this also found in other fruit like oranges (Prabasari et.al., 2011).

\section{Non-destructive methods in fruit maturity detection}

The sum of $R$ and $G$ was quite far between stage 1,2 and 3 . When the values were put into scatter plot, the pattern indicated obvious group between stage 1, 2 and 3 as shown in Figure 6 and 7. However in stage 4, 5 and 6 , the pattern of scatter plot between stages was slightly overlapped. Meanwhile scatter plot from sum of B did not show distinguish groups particularly between stages 4,5 and 6 as shown in Figure 8. The result of sum of R, G and B was in line with the result of visual detection (data not shown) showing that differentiation between stages 1, 2, and 3 was easier than differentiation between stages 4,5 and 6 .

Means of R, G and B were put into scatter plot and the result is shown in Figure 9, 10 and 11.

Table 1. Result of Training and Testing of Svm to Detect Mangosteen Maturity

\begin{tabular}{lllll}
\hline Stage & $\begin{array}{c}\text { Sum of image } \\
\text { testing }\end{array}$ & $\begin{array}{c}\text { Sum of images } \\
\text { classified correctly }\end{array}$ & $\begin{array}{c}\text { Accuracy of } \\
\text { classification (\%) }\end{array}$ & Note \\
\hline 1 & 8 & 8 & 100.0 & - \\
2 & 8 & 8 & 100.0 & - \\
3 & 8 & 7 & 87.5 & 1 image classified as stage 4 \\
4 & 8 & 4 & 50.0 & 1 image classified as stage 3 meanwhile 3 images classified as stage 5 \\
5 & 8 & 5 & 62.5 & 3 images detected as stage 4 whereas 2 images detected as stage 6 \\
6 & 8 & 8 & 87.5 & - \\
\hline
\end{tabular}


The pattern resulted was similar to the pattern from sum of R, G and B. Obvious grouping can be detected clearly between stages although slightly overlapped grouping was found in stage 4, 5 and 6. The scatter plot from the sum and mean of $\mathrm{R}$, $\mathrm{G}$ and $\mathrm{B}$ when counted together indicated characteristics of grouping of R, G and B and showed that it was possible to be used as a non destructive methods to diffrentiate stages of mangosteen.

Two characteristics resulted from sum and mean of $R, G$ and $B$ were used as input for training and testing of SVM as shown in Table 1. In stage 1 and 2 , the accuracy was $100 \%$ whereas in other stages were between 50 and $85 \%$. In summary, the mean of accuracy in detecting mangosteen maturity was $83.3 \%$.

\section{CONCLUSION}

In conclusion, destructive methods showed characteristics of chemical compound changes during senescence and when the same samples were used to examine non-destructive methods using image processing technology it showed the accuracy in detecting mangosteen maturity with the level of $83.3 \%$.

\section{REFERENCES}

Fu, C., Loo, A.E., Chia, F.P., Huang, D. (2007). Oligomeric Proanthocyanidins from Mangosteen Pericarps. J. Agric. Food Chem. 55 (19): 7689-7694

Giusti, M.M. dan Wrolstad, R.E. (1996). Characterization of Red Radish Anthocyanins. J. Food. Sci. 61 (2): 322326

Ji, X., Avula, B., Khan, I.A. (2007). Quantitative and Qualitative Determination of Six Xanthones in Garcinia mangostana L. by LC-PDA and LC-ESI-MS. J. Pharm. Biomed. Anal. 43 (4): 1270-1276

Lestario, L.N., Rahayuni, E., Timotius K.H. (2011). Kandungan Antosianin dan Identifikasi Antosianidin dari Kulit Buah Jenitri (Elaeocarpus angustifolius Blume). AGRITECH 31 (2):93-101

Nandi, C.S., Tudu, B., and Koley, C. (2014). Computer Vision Based Mango Fruit Grading System. International Conference on Innovative Engineering Technologies (ICIET 2014) Dec. 28-29, Bangkok Thailand

Palapol, Y., Ketsa, S., Stevenson, D., Cooney, J.M., Allan, A.C., Ferguson, I.B., (2009). Colour Development and Quality Of Mangosteen (Garcia mangostana L.) Fruit During Ripening and After Harvest. Postharvest Biol and Tech 51 (3): 349-353

Paull, R.E., Ketsa, S. (2004). Mangosteen. In: Gross, K.C., Wang, C.Y., Saltveit, M.E. (Eds.), The Commercial storage of fruits vegetables and florist and nursery stocks

Prabasari, I., Pettolina, F.P., Liao, M.L., Bacic, T. 2011. Pectic Polysaccharides from Mature Orange (Citrus Sinensis) Fruit Albedo Cell Walls: Sequential Exreaxtion and Chemical Characterization. Carbohydrate Polymers 84 (1): 484-494

Riyadi, S., Husain, H., Mustafa, M.M., and Hussain A. 2007a. Papaya Fruit Grading Based on Size Using Image Analysis. Proceeding of the International Conference on Electrical Engineering and Informatics 2007. 645-648p

Riyadi, S., Rani, A.A.A., Mustafa, M.M., and Hussain, A. 2007b. Shape Characteristic Analysis for Papaya Size Classification. Proceeding of the $5^{\text {th }}$ Student Conference on Research and Development 2007. 347-351p

Suyanti dan Setyadjit (2007). Teknologi Penanganan Buah Manggis untuk Mempertahankan Mutu Selama Penyimpanan. Buletin Teknologi Pascapanen Pertanian 3 (1): 66-73

Tongdee, S.C., Suwanagul, A. (1989). Postharvest Mechanical Damage in Mangosteen. ASEAN Food J. 4 (4) 151-155

Ozela, E.F., Stringheta, P.C. dan Milton, C.C. (2007). Stability of Anthocyanin in Spinach Vine (Basella rubra) Fruits. Cien. Inv. Agr. 34 (2): 115120 